Virgil's Ascraean Song: Ramus Essays on the Georgics, edited by A.J. Boyle.

A publication in book form of the special number of Ramus (Vol. 8 no. 1, 1979) devoted to the Georgics. As well as seven essays by distinguished scholars in the field, this volume incorporates an introduction and an index of passages cited.

Paper, 124pp. $\quad$ ISBN $0949916021 \quad$ A $\$ 24.00$ US\$18.00 fstg10.80 (recommended)

Seneca Tragicus: Ramus Essays on Senecan Drama, edited by A.J. Boyle.

This volume contains the twelve essays on the plays of Seneca that were commissioned for Ramus Vol. 12 (1983). This original and unique collection (the only one so far published in English) covers the whole range of Seneca's dramatic output and will be of interest to scholars and students in classics, drama, English and European literature and comparative literature.

Cloth or paper, $256 \mathrm{pp}$.

Hbk ISBN 0949916064 A $\$ 45.00$ US\$33.75 Estg20.25 (recommended)

Pbk ISBN $0949916056 \quad$ A $\$ 30.50$ US $\$ 22.90$ fstg13.70 (recommended)

The Imperial Muse: To Juvenal Through Ovid, edited by A.J. Boyle.

The first of two volumes devoted to Roman literature of the empire, this book version of Ramus Vol. 16 (1987) contains ten essays on authors of the Julio-Claudian and Flavian periods together with an introduction by the editor. As usual, all essays were specially commissioned from experts in their respective fields and reflect a wide range of interests and literary methodology.

Paper, 214pp. $\quad$ ISBN $0949916080 \quad$ A $\$ 30.50$ US\$22.90 Estg13.70 (recommended)

The Imperial Muse: Flavian Epicist to Claudian, edited by A.J. Boyle.

This second volume, the book version of Ramus Vol. 18 (1989) and 19.1 (1990), comprises thirteen essays on Roman literature of the middle and late empire. Authors covered include Statius, Valerius Flaccus, Silius Italicus, Tacitus, Apuleius, Ausonius, Ammianus, Prudentius and Claudian.

Paper, 318pp. ISBN 0949916102 A $\$ 45.00$ US\$33.75 Estg20.25 (recommended)

Roman Literature and Ideology: Ramus Essays for J.P. Sullivan, edited by A.J. Boyle.

In addition to ten specially commissioned essays covering a range of Roman literature from Plautus to Juvenal, this volume contains an appreciation of Sullivan's life and work (including a complete list of his publications in classics and other fields) and the text of the first J.P. Sullivan Annual Lecture given by Professor Boyle at the University of California, Santa Barbara, in March 1994. In the theme on which it focuses and in the quality of its contributions, Roman Literature and ldeology constitutes a worthy tribute to one who did so much to further the study of Roman literature.

Paper, 269pp. $\quad$ ISBN $0949916129 \quad$ A $\$ 49.50$ US\$37.20 £stg22.30 (recommended)

\title{
-texts and translations
}

The Eclogues of Virgil, translated with introduction, notes and Latin text by A.J. Boyle.

As stated by the translator in his preface, the primary purpose of this book is to provide an English translation of Virgil's Eclogues (with exegetic notes and a factual and interpretative introduction) suitable for the student of ancient pastoral who has little or no knowledge of Latin. With its line for line correspondence to and accurate rendition of the original, it constitutes an excellent text for use in courses which study classical literature in translation.

Cloth or paper, 142pp.

Hbk ISBN $094991603 X \quad$ A $\$ 24.00$ US $\$ 18.00$ Estg10.80 (recommended)

Pbk ISBN 0949916048

A $\$ 8.50$ US $\$ 8.00$ Estg5.00 (recommended)

To order-Mail to: Aureal Publications, P O Box 49, Bendigo North, Vic., Australia 3550

Fax to: +61 (0)3 54447970

E-mail to: j.penwill@latrobe.edu.au 